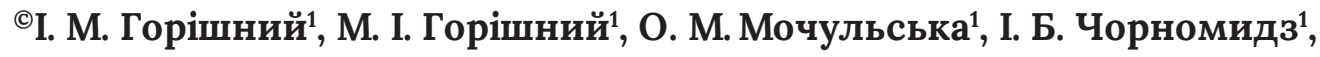
О. Б. Синоверська ${ }^{2}$

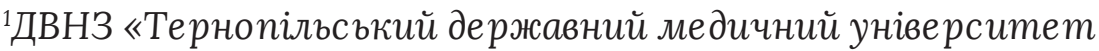

ілені І. Я. Горбачевсъкого МОЗ України»

${ }^{2}$ ДВНЗ «Івано-Франківсъкий державний медичний університет»

\section{ДОСЛІДЖЕННЯ СТАНУ КІСТКОВОЇ ТКАНИНИ В ДІТЕЙ ІЗ ХРОНІЧНИМ ГАСТРОДУОДЕНІТОМ}

\begin{abstract}
Мета дослідження - вивчити біохімічні показники мінерального обміну речовин та результати денситометрії в дітей із хронічним гастродуоденітом.

Матеріали та методи. Обстежено 30 дітей із хронічним гастродуоденітом віком 5-14 років у період загострення хвороби 3 терміном захворювання 1-5 років. Крім загальноприйнятих лабораторних та інструментальних обстежень, проводили денситометрію з визначенням густини кістки в поперековій ділянці хребта, вмісту мінералів у кістці в грамах, площі хребців, висоти та їх об'єму в сантиметрах кубічних, а також біохімічний аналіз крові (кальцій, фросфрор, магній, лужна фоссратаза).

Результати дослідження та їх обговорення. Аналіз отриманих даних показав, що в дітей із хронічним гастродуоденітом порушується мінеральний обмін, змінюється кісткова тканина (остеопороз чи остеосклероз). При остеопорозі на тлі гіпофосфратемії, гіпермагніємії за підвищеної активності лужної фроссратази знижується мінералізація кістки, зменшуються площа й об'єм хребців. При остеосклерозі гіпокальціємія, гіперфоссратемія, гіпермагніємія за нормальної ферментативної активності лужної фроссратази призводять до підвищення мінералізації кістки, збільшення об'єму і площі хребців.

Висновок. Результати досліджень показали наявність ознак остеопорозу та остеосклерозу на тлі порушеного мінерального обміну залежно від активності лужної фоссратази, що вказує на необхідність пошуку методів корекції виявлених змін.
\end{abstract}

Ключові слова: остеопороз; остеосклероз; денситометрія; мінеральний обмін речовин; лужна фоссратаза; гастродуоденіт.

ИССЛЕДОВАНИЕ СОСТОЯНИЯ КОСТНОЙ ТКАНИ У ДЕТЕЙ С ХРОНИЧЕСКИМ ГАСТРОДУОДЕНИТОМ

Цель исследования - изучить биохимические показатели минерального обмена веществ и результаты денситометрии у детей с хроническим гастродуоденитом.

Материалы и методы. Обследовано 30 детей с хроническим гастродуоденитом в возрасте 5-14 лет в период обострения болезни со сроком заболевания 1-5 лет. Кроме общепринятых лабораторных и инструментальных обследований, проводили денситометрию с определением плотности кости в поясничной области позвоночника, содержания минералов в кости в граммах, площади позвонков, высоты и их объема в сантиметрах кубических, а также биохимический анализ крови (кальций, сросфор, магний, щелочная фросфратаза).

Результаты исследования и их обсуждение. Анализ полученных данных показал, что у детей с хроническим гастродуоденитом нарушается минеральный обмен, изменяется костная ткань (остеопороз или остеосклероз). При остеопорозе на фоне гипофоссратемии, гипермагниемии при повышенной активности щелочной фосфратазы снижается минерализация кости, уменьшаются площадь и объем позвонков. При остеосклерозе гипокальциемия, гиперфосфратемия, гипермагниемия при нормальной срерментативной активности щелочной фоосфратазы приводят к повышению минерализации кости, увеличению объема и площади позвонков.

Вывод. Результаты исследований показали наличие признаков остеопороза и остеосклероза на фроне нарушенного минерального обмена в зависимости от активности щелочной фоссратазы, что указывает на необходимость поиска методов коррекции выявленных изменений.

Ключевые слова: остеопороз; остеосклероз; денситометрия; минеральный обмен веществ; щелочная фросфратаза; гастродуоденит.

\section{STUDY OF BONE TISSUE CHANGES IN CHILDREN WITH CHRONIC GASTRODUODENITIS}

The aim of the study - to investigate the biochemical parameters of mineral metabolism and the results of densitometry in children with chronic gastroduodenitis.

Materials and Methods. We examined 30 children with chronic gastroduodenitis aged 5-14 years in the period of exacerbation of the disease, with a disease duration of 1-5 years. In addition to the generally accepted laboratory and instrumental examinations, densitometry was conducted to determine the bone density in the lumbar region of the spine, the content of minerals in the bone in grams, the vertebral area, height and their volume in cubic $\mathrm{cm}$, as well as the biochemical blood test (calcium, phosphorus, magnesium, alkaline phosphatase).

Results and Discussion. Analysis of the data shows that in children with chronic gastroduodenitis, mineral metabolism is disturbed, bone changes develop (osteoporosis or osteosclerosis). With osteoporosis against the backdrop of hypophosphatemia, hypermagneemia, with increased activity of alkaline phosphatase, mineralization of the bone, area and volume of the vertebrae decrease. In osteosclerosis, hypocalcemia, hyperphosphatemia, hypermagneemia with normal enzymatic activity of alkaline phosphatase lead to an increase in bone mineralization, increase in volume and area of the vertebrae. 
Conclusion. The results of the studies showed the presence of signs of osteoporosis and osteosclerosis against the background of disturbed mineral metabolism, depending on the activity of alkaline phosphatase, indicating the need to find correction of the detected changes.

Key words: osteologic pathology; densitometry; mineral metabolism; alkaline phosphatase; gastroduodenitis.

ВСТУП. Хвороби органів травлення - найбільш розповсюджена патологія, серед якої головне місце займає хронічний гастродуоденіт. У 70 \% дітей він розпочинається в дитячому віці й має поєднаний характер ураження органів системи травлення [1]. У патогенезі даної недуги неабияку роль відіграє порушення мембранного і порожнинного травлення зі зміною абсорбції харчових інгредієнтів (білків, жирів, вуглеводів, вітамінів, мікроелементів) у тонкій кишці. Усе це утруднює ріст розвиток дитини, призводить до серйозних обмінних порушень в організмі. 3 огляду на такі міркування, в дітей із хронічним гастродуоденітом слід очікувати зміни мінералізації кісток поряд 3 іншими дисоункціями обміну речовин. Порушення щільності кісткової тканини викликає серйозні ускладнення захворювань та вимагає великих затрат коштів і часу, що не завжди ефективно [2-5]. Тому увага науковців та медиків спрямована перш за все на профрілактику і ранню діагностику цього патоморфологічного стану.

Аналіз доступної літератури показав, що на сьогодні зустрічаються поодинокі роботи, присвячені вивченню остеопорозу в дорослих хворих з гастродуоденальною патологією [6]. Встановлено, що найбільші порушення мінерального обміну спостерігають у хворих на виразкову хворобу з багатолітним стажем, при стенозувальних і пенетрувальних виразках, при супутньому хронічному панкреатиті та в людей похилого віку. В останні роки з'являються повідомлення про остеопенію в дітей і підлітків $[7,8]$. Проте вивчення цієї проблеми при хронічній гастродуоденальній патології в дітей перебуває в початковій стадії.

МЕТА ДОСЛІДЖЕННЯ - ВИвЧИТИ біохімічні показникИ мінерального обміну речовин та результати денситометрії в дітей із хронічним гастродуоденітом.

МАТЕРІАЛИ ТА МЕТОДИ. МИ спостерігали й обстежили 30 дітей із хронічним гастродуоденітом віком 514 років у період загострення хвороби з терміном захворювання 1-5 років. Крім загальноприйнятих лабораторних та інструментальних обстежень, що допомогли верифрікувати основний діагноз, пацієнтам проводили денситометрію з визначенням густини кістки в попере- ковій ділянці хребта, вмісту мінералів у кістці в грамах, площі хребців, висоти та їх об'єму в сантиметрах кубічних, а також біохімічний аналіз крові (кальцій, фоссрор, магній, лужна фоосфатаза).

РЕЗУЛЬТАТИ ДОСЛІДЖЕННЯ ТА ЇХ ОБГОВОРЕНня. Результати досліджень показали, що лише в однієї дівчинки змін з боку кісток не спостерігали. Тривалість захворювання становила 3 роки. На перший план виступали прояви холецистохолангіту, тому гастродуоденіт вважали супутнім захворюванням. Секреторна фрункція шлунка була збережена. Під час біохімічного аналізу в крові виявлено гіпокальціємію, гіпермагніємію, гіперфоссратемію і нормальну активність лужної фоосфатази, що свідчить про порушення мінерального обміну, які $\epsilon$ передумовою подальших змін кісткової тканини. Можна висловити припущення, що в даному випадку відіграли роль вторинний характер гастродуоденальної патології і невелика тривалість захворювання.

У всіх інших дітей $((93,3 \pm 0,7) \%)$ виявлено явища остеопорозу (І група - $(46,7 \pm 1,9) \%)$ чи остеосклерозу (II група - $(46,7 \pm 1,9) \%)$.

Дослідження вмісту кальцію, фросфрору, магнію в крові та активності лужної фроссратази показало, що у двох групах обстежених дітей спостерігались гіпокальціємія і гіпермагніємія. У дітей з остеопорозом хребців виявлено нормофосоратемію при підвищеній активності лужної фоссратази (табл. 1).

У дітей з остеосклерозом (II група) визначалась гіперфоссратемія при нормальній активності лужної фоосфатази (табл. 2).

Таким чином, зміни кісткової тканини залежали від активності лужної фросфратази і відбувались на тлі порушеного мінерального обміну.

Проведення денситометрії в дітей із хронічною гастродуоденальною патологією дозволило поділити їх на 2 групи. В дітей з остеопорозом хребців (I група) десріцит мінеральної щільності кісток становив у середньому $(13,7 \pm 2,5) \%$. У дітей з остеосклерозом (II група) надлишок мінеральної щільності кісток складав у середньому $(21,29 \pm 3,1) \%$. Результати обстежень наведено в таблиці 3.

Таблиця 1. Показники мінерального обміну й активності лужної фосфратази в дітей з остеопорозом (M士m)

\begin{tabular}{|l|c|c|}
\hline \multicolumn{1}{|c|}{ Показник } & Норми біохімічних показників & Результати обстеження хворих I групи \\
\hline Кальцій, ммоль/л & $2,75-3,20$ & $2,18 \pm 0,22$ \\
Фосрор, ммоль/л & $1,29-2,26$ & $1,30 \pm 0,08$ \\
Магній, ммоль/л & $0,10-1,20$ & $1,78 \pm 0,30$ \\
Лужна фросфратаза, ум. од. & $1200-6300$ & $6639 \pm 122$ \\
\hline
\end{tabular}

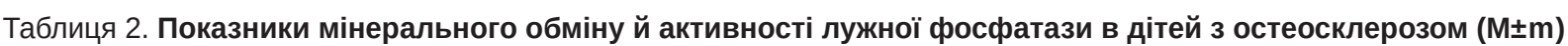

\begin{tabular}{|l|c|c|}
\hline \multicolumn{1}{|c|}{ Показник } & Норми біохімічних показників & Результати обстеження хворих I групи \\
\hline Кальцій, ммоль/л & $2,75-3,20$ & $2,25 \pm 0,18$ \\
Фосфрор, ммоль/л & $1,29-2,26$ & $1,37 \pm 0,12$ \\
Магній, ммоль/л & $0,10-1,20$ & $1,48 \pm 0,15$ \\
Лужна фросфратаза, ум. од. & $1200-6300$ & $3431,5 \pm 108,0$ \\
\hline
\end{tabular}


Таблиця 3. Результати денситометрії в дітей із хронічним гастродуоденітом

\begin{tabular}{|c|c|c|}
\hline Показники & I група дітей & II група дітей \\
\hline Мінеральна щільність, \% & $13,71 \pm 2,50$ & $\begin{array}{c}21,29 \pm 3,10 \\
p \leq 0,05\end{array}$ \\
\hline Вміст мінералів, г & $13,80 \pm 2,40$ & $\begin{array}{c}18,20 \pm 1,20 \\
p<0,05\end{array}$ \\
\hline Густина кістки на 2 см ширини & $3,97 \pm 1,20$ & $\begin{array}{c}5,01 \pm 0,80 \\
p>0,05\end{array}$ \\
\hline Площа хребців, см² & $16,92 \pm 1,11$ & $\begin{array}{c}19,65 \pm 0,51 \\
p<0,05\end{array}$ \\
\hline Висота хребців, см & $5,57 \pm 0,32$ & $\begin{array}{c}5,64 \pm 0,51 \\
p>0,05\end{array}$ \\
\hline Об'єм хребців, см³ & $66,40 \pm 0,70$ & $\begin{array}{c}68,20 \pm 0,30 \\
p<0,05\end{array}$ \\
\hline
\end{tabular}

Примітка. p - достовірність різниці I і II груп дітей.

Таким чином, при остеопорозі знижувався вміст мінералів у кістці, зменшувались площа й об'єм хребця при збережених висоті хребця та густині кістки на 1 см ширини. При остеосклерозі, навпаки, підвищувався вміст мінералів, збільшувались площа та об'єм хребців.

Висновки. Аналіз отриманих даних показує, що в дітей із хронічним гастродуоденітом порушується мінеральний обмін, змінюється кісткова тканина (остеопороз чи остеосклероз). При остеопорозі на тлі гіпофоссратемії, гіпермагніємії за підвищеної активності лужної фроссратази знижується мінералізація кістки, зменшуються площа й об'єм хребців. При остеосклерозі гіпокальціємія, гіперфоссратемія, гіпермагніємія за нормальної фрерментативної активності лужної фоосратази призводять до підвищення мінералізації кістки, збільшення об'єму і площі хребців. Густина кістки і висота хребців не змінюються, що вказує на можливість пошуку методів корекції виявлених змін.

ПЕРСПЕКТИВИ ПОДАЛЬШИХ ДОСЛІДЖЕНЬ. БУДР продовжено вивчення віддалених результатів остеопорозу та остеосклерозу на тлі порушеного мінерального обміну в дітей із хронічним гастродуоденітом та пошук методів корекції виявлених змін.

\section{СПИСОК ЛІТЕРАТУРИ}

1. Заболевания пищевода, желудка и двенадцатиперстной кишки у детей / В. Г. Майданник, В. В. Корнейчук, Н.В. Хайтович, Г. В. Салтыкова. - К. : ВБ «Аванпост-Прим», 2008. -432 c.

2. Квашніна Л. В. Особливості кальцій-сроссрорного обміну у здорових дітей в сучасних умовах та оптимізація методів профрілактики його порушень / Л. В. Квашніна, Л. І. Апуховська, В. П. Родіонов // Перинатол. та педіатр. 2004. - № 1. - С. 29-32.

3. Малинин В. Л. Эпидемиологические аспекты остеопении у подростков и юношей Санкт-Петербурга / В. Л. Малинин // Травмат. и ортопед. России. - 2006. - № 2. - С. 192.

4. Остеопения у детей: диагностика, профилактика и коррекция : пособ. для врачей / [Л. А. Щеплягина, Т. Ю. Моисеева, М. В. Коваленко и др.]. - М., 2005. - 40 с.

\section{REFERENCES}

1. Maydannik, V.G. Korneychuk V.V., Khaytovich, N.V., \& Saltikova, G.V. (2008). Zabolevaniya pishchevoda, zheludka i dvenadsatyperstnoy kishky u detey [Diseases of the esophagus, stomach and duodenum in children]. Kiev: VB "Avanpost-Prym" [in Ukrainian].

2. Kvashnina, L.V., Apukhovska, L.I., \& Rodionov, V.P. (2004). Osoblyvosti kaltsii fosfornoho obminu u zdorovykh ditei v suchasnykh umovakh ta optymizatsiia metodiv profilaktyky yoho porushen [Features of calcium phosphorus metabolism in adolescent children in contemporary conditions and optimization of the methods of prolacting its disorders]. Perynatolohiia ta pediatriia - Perinatology and Pediatrics, 1, 29-32 [in Ukrainian].

3. Malinin, V.L. (2006). Epidemiologicheskiye aspekty osteopenii u podrostkov i yunoshey Sankt-Peterburga [Epidemiological aspects of osteopenia in teenagers and young men of St. Petersburg]. Travmatologiya i ortopediya Rossii Traumatology and Orthopedics, 2, 192 [in Russian].

4. Shcheplyagina, L.A., Moyseeva, T.Yu., \& Kovalenko, M.V. (2005). Osteopeniya u detey: diagnostika, profilaktika i korrektsiya: posob. dlya vrachey [Epidemiological aspects of osteopenia in teenagers and young men: guidelines for doctors]. Moscow [in Russian].

5. Povorozniuk, V.V. (2004). Zakhvoriuvannia kistkovomiazovoi systemy v liudei riznoho viku (vybrani lektsii ohliady, 


\section{Педіатрія}

statti): u $2 t$. [Diseases of the bone and myaenoic system in people of all ages (selected lectures, reviews, articles): in 2 vol.]. Kyiv [in Ukrainiain].

6. Povorozniuk, V.V. (1999). Strukturno-funktsionalnyi stan kistkovoi tkanyny u ditei ta pidlitkiv Ukrainy: dani ultrazvukovo densytometrii [Structural and functional state of bone tissue in children and adolescents in Ukraine: data of ultrasonic densitometry]. Pediatriia, akusherstvo ta hinekolohiia - Pediatrics, Obstetrics and Gynecology, 4, 154 [in Ukrainian].

7. Frank, R. Greeg, \& Nancy, F. Krebs (2006). Optimizing bone health and calcium intakes of infants, children, and adolescents. Pediatrics, 117, 2, 578-585.

8. Kinuta, K., \& Seino, Y. (2004). Prevention of osteoporosis in childhood adolescence. Clin. Calcium, 14 (11), 1709-1713.

Отримано 12.02 .19 